\title{
IMPLEMENTACIJA PRISTUPA TEMELJENOG NA DOKAZIMA UČINKOVITOSTI U PREVENCIJSKOJ ZNANOSTI
}

\author{
Matea Belošević \\ Martina Ferić \\ Laboratorij za prevencijska istraživanja (PrevLab), Odsjek za poremećaje u \\ ponašanju, Edukacijsko - rehabilitacijski fakultet Sveučilišta u Zagrebu \\ E-mail: matea.belosevic@erf.unizg.hr
}

\begin{abstract}
SAŽETAK
Svrha rada je dati kritički osvrt na pristup temeljen na dokazima učinkovitosti, od definiranja ključnih pojmova do analize prednosti i prepreka za njegovu implementaciju u praksu. U radu se raspravlja o pristupu utemeljenosti na dokazima učinkovitosti, odnosno definiraju se pojmovi „praksa temeljena na dokazima učinkovitosti” i „programi/intervencije temeljene na dokazima učinkovitosti“. Kritički se osvrće na ključne kriterije programa/intervencija temeljenih na dokazima učinkovitosti. Opisane su najznačajnije online baze učinkovitih programa i kategorije koje se koriste pri određivanju razine učinkovitosti programa/intervencija. Nadalje, raspravlja se i kritički osvrće na prednosti, ali i izazove korištenja pristupa temeljenog na dokazima učinkovitosti i kao i pri njegovoj implementaciji. Zaključno su predložene smjernice za buduća istraživanja te djelotvoran i učinkovit odabir i primjenu pristupa temeljenog na dokazima učinkovitosti u prevencijsku praksu.

Ključne riječi: prevencijska znanost, programi, pristup temeljen na dokazima učinkovitosti, prednosti, prepreke
\end{abstract}

\section{UVOD}

Prevencijska znanost ima za cilj utvrditi rizične i zaštitne čimbenike na individualnoj razini te na razini okruženja u kojima individua živi, koji promoviraju pozitivan razvoj, odnosno vode rizičnim ponašanjima i/ili problemima u ponašanju. Već više od 50 godina u području prevencijske znanosti kreiraju se programi, strategije i politike koje poboljšavaju pozitivne razvojne ishode i smanjuju negativne zdravstvene/socijalne ishode jačajući uvjete koji omogućavaju pojedincima, obitelji i zajednicama zdravi razvoj. Pri tome, prevencijska znanost je usredotočena na razvoj i implementaciju intervencija temeljenih na dokazima učinkovitosti te taj proces postaje jedno od njezinih ključnih načela.

Pristup temeljen na dokazima učinkovitosti (eng. evidence-based approach) pojavio se u medicini krajem 20. stoljeća, a slijedili su ga stručnjaci za javno zdravstvo i mentalno zdravlje. Kao rezultat napora i ulaganja mnogih znanstvenika i praktičara, danas postoje dokazi koji služe kao 
nit vodilja u definiranju prakse i politika temeljenih na dokazima učinkovitosti (Anderson, 2019; Evidence-Based Medicine Working Group, 1992; Tucker i Reed, 2008). lako je pristup temeljen na dokazima učinkovitosti najistaknutiji u Ujedinjenom Kraljevstvu, Kanadi i Sjedinjenim Američkim Državama, sve popularniji postaje u mnogim europskim zemljama te se mjerenje ishoda i učinkovitost javnih usluga za koje vlade i građani smatraju da su važni, sve više primjenjuju (Mullen i Streine, 2004). Posljednjih nekoliko godina, sintagma "temeljeno na dokazima” postaje dio svakodnevnog rječnika i učestalo se upotrebljava u stručnoj i znanstvenoj javnosti. Rastuća upotreba ove sintagme, sugerira da navedeno postaje trend, ali i da se nastoji odgovoriti na niz složenih i „otvorenih" pitanja vezanih uz pristup temeljen na dokazima učinkovitosti, od njegove definicije do sličnosti i razlika s terminima koji se koriste kako bi se opisalo, najšire rečeno, djelovanje temeljeno na dokazima učinkovitosti. Uz navedeno, mnogo je znanstvenih i stručnih rasprava o prednostima i izazovima pristupa temeljenog na dokazima učinkovitosti pri implementaciji intervencija u stvarna okruženja.

U kontekstu prevencijske znanosti, na dokazima učinkovitosti temeljena praksa (eng. evidence based practice, EBP), na dokazima učinkovitosti temeljene intervencije (eng. evidence-based intervention, EBI) te na dokazima učinkovitosti temeljeni procesi (eng. evidence-based process, EBP), široki su pojmovi koji se često koriste naizmjenično, a odnose se prvenstveno na procese korištenja znanstvenih dokaza pri planiranju i implementaciji preventivnih intervencija.

Svrha ovog rada jest kritički se osvrnuti na pristup temeljen na dokazima učinkovitosti, od definiranja do analize prednosti i prepreka za njegovu implementaciju te donijeti zaključak na temelju cjelokupne analize. $U$ odnosu na svrhu rada postavljeni su ciljevi koji se odnose na definiranje pristupa temeljenog na dokazima učinkovitosti, osvrt na ključne kriterije koje trebaju zadovoljiti programi/intervencije da bi bile temeljene na dokazima učinkovitosti te se raspravlja o prednostima i izazovima implementacije pristupa temeljenog na dokazima učinkovitosti u praksu. Ciljevi rada postižu se pregledom recentne literature, kritičkim osvrtom te sintezom dosadašnjih spoznaja u području prevencijske znanosti.

\section{PRISTUP TEMELJEN NA DOKAZIMA UČINKOVITOSTI}

Danas postoji rastuća potražnja za učinkovitim intervencijama te je taj rast popraćen zbunjenošću koja se odnosi na različite pojmove koji se koriste kako bi se imenovao i/ili opisao pristup temeljen na dokazima učinkovitosti (Mihalic i Elliott, 2015). Pregledom literature i načina kako različiti autori (i/ili istraživačke grupe) definiraju i koriste pojedinačne sintagme (programi temeljeni na dokazima učinkovitosti, intervencije temeljene na dokazima učinkovitosti, praksa temeljena na dokazima učinkovitosti, procesi temeljeni na dokazima učinkovitosti, znanstveno temeljena praksa, znanstveno temeljene intervencije) moguće je uočiti da svi na isti način definiraju "dokaze" dok se različitosti u definicijama odnose na definiranje "prakse“, „programa ili intervencija” i „procesa”.

Tako se dokazi, unutar raznih definicija, najčešće definiraju kao znanstveni dokazi dobiveni (rigoroznim) znanstvenim postupcima kroz eksperimentalna istraživanja (Brownson, Fielding i Maylahn, 2009; Bumbarger i Owen, 2009; Crime and Justice Institute, 2009; European Monitoring Centre for Drugs and Drug Addiction, 2019; Gottfredson i sur. 2015; Health Policy Institute of Ohio (HPIO), 2013; Portney, 2020; U.S. Department of Health and Human Services (u daljnjem tekstu: 
HHS), 2016; Washington State Institute of Public Policy's, 2012). Pri tome, kada se opisuju istraživanja izvrsne kvalitete, najčešće se spominje eksperiment sa slučajnim rasporedom ispitanika u skupine (eng. Randomized Controlled Trial - u daljnjem tekstu: RCT) koji predstavlja zlatni standard nacrta istraživanja. Budući da se radi o istraživanjima u kojima postoji kontrolna skupina, a ispitanici se po slučaju raspoređuju u eksperimentalnu ili u kontrolnu skupinu, RCT istraživanja predstavljaju nacrt evaluacije koji pruža najjači dokaz da se pozitivni rezultati mogu pripisati programu koji se procjenjuje (Hariton i Locascio, 2018; McKay, 2007; Tomlinson, Ward i Marlow, 2015). Također, važno je repliciranje pozitivnih nalaza u višestrukim istraživanjima kako bi osigurali da se program može generalizirati na različite populacije $i$ kontekste te da učinak programa nije samo rezultat kontrole istraživača nad istraživanjem (Bumbarger i Owen, 2009; Hariton i Locascio, 2018).

Na dokazima učinkovitosti temeljena praksa ili znanstveno temeljena praksa definira se kao sustavni proces donošenja odluka ili pružanja usluga za koje postoje dostupni znanstveni dokazi koji potvrđuju da određena praksa dosljedno poboljšava mjerljive ishode korisnika; znanstveno temeljena praksa oslanja se na podatke prikupljene u okviru istraživanja i uzima u obzir obilježja pojedinih klijenata i stručnost praktičara (Andrews i Bonta 2012; Brownson i sur. 2009; Crime and Justice Institute, 2009; HHS, 2016).

Na dokazima učinkovitosti temeljeni programi ili intervencije koriste definirane kurikulume, intervencijske modele, tehnike ili skupove aktivnosti (usluge) koje su, pri vjernoj implementaciji, dokazane kao učinkovite kroz znanstvene procese (HHS, 2016). Health Policy Institute of Ohio (HPIO, 2013) na dokazima učinkovitosti temeljene preventive strategije definira kao programe, politike ili druge strategije koje su evaluirane i koje su pokazale učinkovitost temeljem najboljih dostupnih znanstvenih dokaza, a ne na temelju osobnih dojmova ili anegdotalnih dokaza. Na sličan način programe/intervencije temeljene na dokazima učinkovitosti koriste i drugi autori (Andrews i Bonta, 2012; Hailemariam, Bustos, Montgomery, Barajas, Evans i Drahita, 2019; Przybylski i Orchowsky, 2015; Steglitz, Warnik, Hoffmn, Johnston i Spring, 2015; Williams-Taylor, 2007). Korištenje intervencija (prakse, programa, strategija) temeljenih na dokazima učinkovitosti, najjednostavnije znači, identificiranje najboljih dostupnih znanstvenih dokaza te kombiniranje tih dokaza s drugim čimbenicima u kontekstu u kojem se intervencija implementira. Praksa, programi i strategije temeljene na dokazima učinkovitosti integriraju znanstvene dokaze s iskustvom praktičara (ekspertizom) i dostupnim resursima u kontekstu u kojem se implementiraju.

Na dokazima učinkovitosti temeljene intervencije mogu se razvrstati na nekoliko razina „snage dokaza" ovisno o rigoroznosti znanstvenih postupaka kojima je dokazana njihova učinkovitost. U tom kontekstu, pojam "temeljen na dokazima" koristi se kao "pečat odobrenja” kako bi se naznačilo da je riječ o određenom programu ili strategiji koja je ocijenjena i za koju je dokazano da je učinkovita. Taj „pečat odobrenja” mogu dati znanstvenici, stručni odbori ili agencije koje su pregledale dokaze o programu ili pak neovisne organizacije koje su procjenjivale učinkovitost programa (HPIO, 2013). Tri su koncepta korisna za razumijevanje onoga što se podrazumijeva pod pojmom "temeljeno na dokazima” (HPIO, 2013):

1. Vrste dokaza na temelju kojih se donose odluke: najbolji dostupni dokazi istraživanja, iskustveni dokazi i kontekstualni dokazi; 
2. Razina učinkovitosti u postizanju željenih ishoda: kontinuum od visoko učinkovitih do neučinkovitih ili čak štetnih pristupa;

3. Snaga znanstvenih dokaza: kontinuum iz dobro potkrijepljenih rigoroznih metoda istraživanja do neodređenih programa koji još nisu ocijenjeni.

Za postizanje učinkovitih rezultata, moraju se donijeti odluke o tome kako optimalno osmisliti, implementirati i vrednovati intervencije. Takve odluke ne bi se trebale donositi na temelju intuicije ili nasumično, već bi praktičari trebali biti obučeni da poduzimaju informirane akcije na temelju znanja (Rith-Najarian, Daleiden i Chorpita, 2016; Rousseau i Gunia, 2016). Donošenje odluka na temelju znanstvenih dokaza postaje pomalo kompliciran zadatak. S obzirom na to da je informacija mnogo te da ih je sve više, moguće je da se međusobno razlikuju od izvora do izvora. Ipak, danas postoje dovoljno jasni ključni kriteriji o tome što se smatra intervencijom temeljenom na dokazima učinkovitosti te je nužno poznavanje istih kako bi se olakšao proces donošenja odluka prilikom implementacije programa u praksu. Imperativ je implementirati učinkovite intervencije koje dobro odgovaraju potrebama zajednice.

Kao što je već ranije spomenuto, intervencije koje se temelje na dokazima učinkovitosti izgrađene su na čvrstim znanstvenim teoretskim temeljima, pažljivo su provedene i vrednovane pomoću strogih znanstvenih metoda. Ove metode obično uključuju longitudinalni nacrt, jasno definirane i mjerljive varijable te kontrolnu i eksperimentalnu skupinu. U idealnom slučaju, intervencije su ocijenjene u različitim okruženjima, a rezultati evaluacije bili su podvrgnuti kritičkom pregledu drugih istraživača te su objavljeni u uglednim znanstvenim časopisima (Small i Huser, 2016). Praktičari koji traže učinkovit program prevencije za provedbu u svojoj zajednici ili jednostavno žele saznati više o programima, pronaći će Internet kao mjesto najboljeg izvora. Brojne agencije i istraživači uspostavili su procese za pregled i popis programa koji ispunjavaju standarde učinkovitosti. Većina tih agencija izradila je online baze u kojima se nalaze popisi programa te su navedene razine njihove učinkovitosti (Small i Huser, 2016).

Neke od najznačajnih on-line baza programa nalaze se u Tablici 1. (modificirano prema Small i Huser, 2016, i European Monitoring Centre for Drugs and Drug Addiction, 2019). U istoj Tablici je moguće vidjeti kategorije učinkovitosti koje pojedina baza koristi.

Tablica 1. Izbor on-line registra učinkovitih programa/ intervencija

\begin{tabular}{|c|c|c|}
\hline NAZIV ON-LINE REGISTAR & INTERNET ADRESA & $\begin{array}{l}\text { KATEGORIJE UČINKOVITOSTI } \\
\text { PROGRAMA }\end{array}$ \\
\hline $\begin{array}{c}\text { Xchange } \\
\text { Eurpean monitoring center for Drugs and Drug } \\
\text { Addiction (EMCCDA) }\end{array}$ & $\begin{array}{c}\text { http://www.emcdda.europa.eu/ } \\
\text { best-practice/xchange }\end{array}$ & $\begin{array}{l}\text { - djelotvoran } \\
\text { - vjerojatno djelotvoran } \\
\text { - moguće djelotvoran } \\
\text { - preporučuju se dodatna istraživanja } \\
\text { - vjerojatno nedjelotvoran }\end{array}$ \\
\hline $\begin{array}{l}\text { Blueprints } \\
\text { Blueprints for Healthy Youth Development } \\
\text { University of Colorado Boulder }\end{array}$ & https://www.blueprintsprograms.org & $\begin{array}{l}\text { - obećavajući } \\
\text { - model } \\
\text { - model plus }\end{array}$ \\
\hline $\begin{array}{c}\text { The What Works Clearinghouse } \\
\text { Institute of Educational Sciences (IES), U.S. } \\
\text { Department of Education }\end{array}$ & http://ies.ed.gov/ncee/wwc/ & $\begin{array}{l}\text { - pozitivni ili potencijalno pozitivni } \\
\text { učinci } \\
\text { - različiti učinci/nisu primjetni } \\
\text { — nema dokaza }\end{array}$ \\
\hline $\begin{array}{l}\text { Model Programs Guide } \\
\text { Office of Juvenile Justice and Delinquency } \\
\text { Prevention, U.S. }\end{array}$ & https://www.ojjdp.gov/mpg & $\begin{array}{l}\text { - učinkoviti } \\
\text { - obećavajući } \\
\text { - neučinkoviti }\end{array}$ \\
\hline
\end{tabular}


U odnosu na kategorije učinkovitosti po kojima različite on-line baze procjenjuju učinkovitost programa, koriste se različiti termini, no kriteriji za pojedinu kategoriju učinkovitosti su vrlo slični.

Tako su u on-line bazi Xchange (EMCDDA) ${ }^{1}$ kategorije učinkovitosti intervencija označene kao:

- Djelotvorne: intervencije za koje utvrđeni uvjerljivi, dosljedni i trajni učinci na relevantne ishode intervencije u dvije ili više istraživanja izvrsne kvalitete u Europi.

- Vjerojatno će biti djelotvorne: intervencije za koje su utvrđeni uvjerljivi i konzistentni učinci na relevantne ishode intervencije u barem jednom evaluacijskom istraživanju izvrsne kvalitete u Europi.

- Moguće djelotvorne: intervencije za koje su utvrđeni neki učinci na relevantne ishode intervencije $u$ barem jednom evaluacijskom istraživanju prihvatljive kvalitete u Europi. Intervencija ocijenjena kao "moguće djelotvorna" pogodna je za primjenu u kontekstu rigoroznijih procjena.

- Preporučena dodatna istraživanja: intervencije kod kojih postoji pitanje oko kvalitete evaluacijskih istraživanja ili rezultati nisu dosljedni u Europi te je otežana procjena jesu li učinkoviti ili ne, čak i ako se čini da intervencija ima pozitivne ishode.

- Vjerojatno nije djelotvorna: intervencije za koje barem jedno evaluacijsko istraživanja izvrsne kvalitete u Europi pokazuje uvjerljive dokaze o nepostojanju pozitivnih ishoda ili štetnom utjecaju na relevantne ishode intervencije.

Bluprints $^{2}$ on-line baza programa programe kategorizira u tri kategorije:

- Obećavajući programi - oni zadovoljavaju sljedeće standarde: (1) specifičnost intervencije: opis intervencije jasno identificira planirani ishod(e), ishodi su usmjereni na određeni rizik i /ili zaštitne čimbenike koji bi proizveli planiranu promjenu, populacija kojoj je intervencija namijenjena je primjerena i komponente intervencije mogu dovesti do planiranih ishoda; (2) kvaliteta evaluacije - evaluacijska istraživanja daju valjane i pouzdane rezultate; (3) učinak intervencije - rezultati kvalitetnih evaluacijskih istraživanja ukazuju na značajnu pozitivnu promjenu kod planiranih ishoda koja se može pripisati intervenciji i nema dokaza o štetnim učincima; (4) spremnost za širenje - intervencija je trenutno dostupna za širenje i ima potrebne organizacijske kapacitete, priručnike, trening, tehničku pomoć i drugu podršku potrebnu za vjernu implementaciju intervencije u zajednicama i sustavima javnih usluga.

- Model programi - uz navedene standarde koji vrijede za obećavajuće programe, model programi zadovoljavaju i sljedeće standarde: (1) ponavljanje evaluacijskih istraživanja: najmanje dva RCT istraživanja izvrsne kvalitete ili jedno RCT istraživanje i jedno kvazieksperimentalno istraživanje izvrsne kvalitete; (2) dugoročno praćenje: pozitivan učinak intervencije održava se najmanje 12 mjeseci nakon završetka programa.

https://www.emcdda.europa.eu/best-practice/xchange/about

https://www.blueprintsprograms.org/blueprints-certification/ 
- Model plus programi - uz sve navede standarde u prve dvije kategorije zadovoljavaju i standard provedenog neovisnog evaluacijskog istraživanja izvrsne kvalitete u kojem su potvrđeni pozitivni učinci intervencije, a koje je (istraživanje) osmislio i proveo autor koji nije ni trenutni ni bivši član istraživačkog tima programa i koji nema financijskog interesa u programu.

U The What Works Clearinghouse ${ }^{3}$ on-line bazi programa su programi rangirani u tri kategorije: „pozitivni ili potencijalno pozitivni učinci“, „različiti učinci/nisu primjetni” i "nema dokaza”. Ova on-line baza koristi sljedeće standarde kako bi se procijenila snaga istraživačke metodologije evaluacijskih istraživanja: (1) vrsta nacrta u kojoj se koristi RCT istraživanje, kvazieksperimentalni nacrt istraživanja, nacrt diskontinuiteta regresije ili nacrt istraživanja pojedinačnih slučajeva), (2) snagu prikupljenih podataka (vrste ishoda koje ona mjeri, stope odgovora na prikupljanje podataka) i (3) prikladnost statističkih postupaka istraživanja (je li moguće provjeriti rezultate).

Model Programs Guide 4 on-line baza programa rangira intervencije kao (1) učinkovite imaju snažne dokaze da se intervencijom postižu predviđeni ishodi kada su vjerno implementirani, (2) obećavajuće - imaju neke dokaze da se intervencijom postižu predviđeni ishodi, preporučuje se dodatno istraživanje i (3) neučinkoviti - imaju snažne dokaze da se intervencijom nisu postigli predviđeni ishodi kada su se vjerno implementirali.

Postoje određene razlike u kriterijima koje različite agencije uzimaju u obzir kako bi odlučile treba li program podržati i uključiti u njihov registar. Međutim, postoje i značajna preklapanja te svi prepoznaju ključnu važnost potvrđivanja učinkovitosti programa putem rigoroznih, znanstvenih intervencija (Bumbarger i Owen, 2009). Iz navedenog, vidljivo je kako kriteriji za rangiranje u najviše kategorije uvijek jesu evaluacijsko istraživanje (istraživanja) izvrsne kvalitete te dokazani učinci programa kroz vrijeme.

U Hrvatskoj od 2012. godine postoji Baza projekata i programa ${ }^{5}$, koja za sada nije kategorizirana po razini učinkovitosti. Riječ je o bazi projekata i programa koji se provode u području suzbijanja zloporabe druge koji je osmislio i vodi Ured za suzbijanje zlouporabe droga Vlade Republike Hrvatske (sada dio Hrvatskog zavoda za javno zdravstvo) s ciljem identificiranja kvalitetnih, evaluiranih i učinkovitih programa te podizanja razine kvalitete programa i projekata koji se provode u području suzbijanja ovisnosti. Baza sadrži podatke o svim projektima i programima koji se provode u području suzbijanja zlouporabe droga, na temelju Akcijskog plana suzbijanja zlouporabe droga. Omogućava pregled prema nazivu programa, nazivu provoditelja, županiji provedbe, godini provedbe, vrsti provedene evaluacije, razini intervencije te vrstama provedene usluge ili prema glavnoj skupini područja djelovanja. U ovom trenutku ova baza je samo popis projekata, programa, ali i pojedinačnih (jednokratnih) aktivnosti koji se provode u zemlji u području prevencije korištenja sredstava ovisnosti. Intervencije nisu kategorizirane po razini učinkovitosti. Na službenim

http://ies.ed.gov/ncee/wwc/

4 https://www.ojjdp.gov/mpg

5 http://www.programi.uredzadroge.hr/ 
stranicama Ureda za suzbijanje zlouporabe droga Vlade Republike Hrvatske ${ }^{6}$ moguće je naći informaciju kako je osmišljavanje i postavljanje baze programa prvi korak u unaprjeđenju kvalitete programa koji se provode. Naime, sljedeći korak je učinkovitim programima dodijeliti certifikat kvalitete. Certifikate, odnosno procjenu razine učinkovitosti bi dodjeljivalo stručno Povjerenstvo za kvalitetnu prevenciju (osnovano 2017. godine) sukladno kriterijima/standardima koji se primjenjuju u Europi. Navedeno predstavlja značajan izazov s obzirom na to da su evaluacije u RCT istraživanjima rijetkost u hrvatskom kontekstu. Međutim, potrebno je promišljati o osiguravanju sredstva za provedbu takvih istraživanja te poticati upravo provedbu i evaluaciju programa koji imaju potencijala da postanu programi temeljeni na dokazima učinkovitosti. Osiguravanje dostatnih resursa, prvotni je korak pri uspostavljanju programa temeljenih na dokazima učinkovitosti te u skladu s time i dodjeljivanju certifikata kvalitete unutar baze programa.

Zaključno, on-line baze programa su vrijedni resurs u kontekstu pristupa temeljenog na dokazima učinkovitosti. Ipak, pri pretraživanju on-line baza podataka treba ima na umu njihovu vjerodostojnost. Burkhardt, Schröter, Magura, Means i Coryn (2015) ističu kako bi daljnja istraživanja korisnika i načina korištenja on-line baza podataka te uloge evaluacijskih izvještaja (i/ili kriterija za dodijeljene kategorije učinkovitosti) mogla, u budućnosti, unaprijediti vrijednost on-line baza programa za praktičare, istraživače i donositelje odluka. Stvaranje nacionalne on-line baze učinkovitih programa na području prevencije, ali i drugih razina intervencija poput promocije pozitivnog razvoja, tretmana i održavanja stanja bio bi veliki korak u promociji implementacije praksa, programa i strategija temeljenih na znanstvenim dokazima. Učinkovitost napora znanstvenika, praktičara, ali i ključnih ljudi (onih koji donose odluke) bila bi veća ukoliko bi se implementirale dokazano učinkovite intervencije koje bi dovodile do željenih rezultata i time podržale pozitivne ishode za korisnike te društvo u cjelini.

\section{PREDNOSTI KORIŠTENJA PRISTUPA TEMELJENOG NA DOKAZIMA UČINKOVITOSTI}

Na temelju dostupne literature može se zaključiti kako je rijetko koja inovacija proizvela toliko argumenata i žara kao uvođenje pristupa temeljenog na dokazima učinkovitosti. Samim time, postoje brojne prednosti, ali i izazovi korištenja pristupa temeljenog na dokazima učinkovitosti.

Najveća prednost korištenja pristupa temeljenog na dokazima učinkovitosti je jamstvo učinkovitosti programa. Programi koji su dokazali pozitivne rezultate u rigoroznim i dobro provedenim procjenama mogu praktičarima i ključnim ljudima (donosiocima odluka i kreatorima politike) ulijevati sigurnost da će biti učinkoviti. Nasuprot tome, programi koji nemaju dobru empirijsku podršku predstavljaju veći rizik od neuspjeha (Bumbarger i Owen, 2009). Snaga nacrta istraživanja jest značajan kriterij koji definira programe temeljene na dokazima učinkovitosti (Prendergast, 2011; Trinder i Reynolds, 2006).

6 https://drogeiovisnosti.gov.hr/baza-projekata-i-programa-koji-se-provode-u-podrucju-suzbijanja-zlouporabe-droga/938 
Nadalje, značajna prednost jest zasigurno činjenica da različiti dionici mogu imati koristi od primjene pristupa temeljenog na dokazima učinkovitosti. Donosioci odluka i kreatori politika mogu biti zainteresirani ponajprije zbog smanjivanja broja slučajeva rizičnih ponašanja djece i mladih uz pomoć uspješnih preventivnih programa te zbog dobro uloženog novca. Financijeri traže odgovore o isplativosti takvih programa. Istraživači su zainteresirani za dokaze koji će dosegnuti visoke standarde unutarnje valjanosti, dok su organizacije koje okupljaju korisnike usmjerene na zadovoljstvo korisnika, poboljšanje njihova stanja i smanjivanje negativnih učinka intervencija (Hosman i JaneLlopis, 2007, prema Bašić, 2009). Primarna korist i namjeravani ishod korištenja pristupa temeljenog na dokazima učinkovitosti trebao bi biti poboljšanje ishoda za krajnje korisnike i podrška pojedincima u postizanju željene razine udobnosti i autonomije u raznim okruženjima. Važna predanost jest $\mathrm{i}$ sposobnost da se dosljedno i na praktičan način postignu bolji ishodi po korisnike, uz manji trošak za pojedince i društvo (Anderson, 2019). Primjena pristupa temeljenog na dokazima učinkovitosti može pomoći u osiguravanju financiranja i/ili povećati financiranje ključnih programa i usluga (The Resource Center on Domestic Violence, 2016). U današnje doba, kada je fokus na ograničavanju resursa i troškova, dokaz da implementacija programa temeljenih na dokazima učinkovitosti može generirati uštede važna je informacija za donošenje odluka (Mihalic i Elliott, 2015).

Za zagovornike prakse temeljene na dokazima učinkovitosti postoji nepokolebljiva vjera u sposobnost znanosti te sustavnu primjenu znanosti kako bi se postigla učinkovita, djelotvorna i odgovorna praksa. Praksa temeljena na dokazima učinkovitosti predstavlja pristup gdje neutralnost znanosti i transparentnost procesa pružaju mogućnost sudjelovanja i praktičarima i krajnjim korisnicima. Time je moguće riješiti problem u kojem se praktičari rutinski ne okreću istraživačkim spoznajama kako bi riješili dileme u praksi, niti istraživači naprosto rutinski ne postavljaju pitanja ili kreiraju nalaze koji su relevantni i korisni krajnjim korisnicima (Hood, 2002, prema Buysse, Wesley, Snyder i Winton, 2006). Tako praksa temeljena na dokazima učinkovitosti predstavlja sveukupni sustav dijagnosticiranja, metodologije i rješavanja problema jaza između istraživanja i prakse (Trinder i Reynolds, 2006).

Jedan od načina na koji je pokret u praksi temeljenoj na dokazima učinkovitosti pokušao premostiti ovu prazninu jest uključivanjem korisnika i praktičara u izgradnju baze podataka (Wesley i Buysse, 2006, prema Buysse, Wesley, Snyder i Winton, 2006). Sustavno organiziranje znanja iz postojeće prevencijske literature može poslužiti kao analitički alat u osmišljavanju novog programa, odabiru postojećeg programa ili prilagodbi postojećeg programa. lako će zadatak određivanja prioriteta određenih informacija ostati, okruženje bogato znanjem može doprinijeti učestalijem donošenju odluka temeljenih na dokazima učinkovitosti u usporedbi s odlukama donesenim u izoliranom okruženju. Koordiniranje znanja unutar znanstvenika i praktičara u prevencijskoj zajednici može proširiti epistemologiju kako bi se uključilo ne samo ono što je već poznato iz znanstvenih istraživanja, već i ono što je poznato osobama iz mreže koji razumiju vrijednosti i sklonosti svoje zajednice (Rith-Najarian, Daleiden i Chorpita, 2016). Ujedno, mnoge na dokazima učinkovitosti temeljene prakse i programi imaju odgovarajuće priručnike i smjernice za podršku u provedbi usluga i vjernosti određenom modelu, dok neki imaju podršku od strane istraživačkih skupina i/ ili osiguranu podršku na temelju sustavnih procjena meta-analiza koje omogućuju čitateljima da izvuku zaključke na temelju niza istraživanja (McKay, 2007; Pew Cheritable Trust, 2016). Sve navedeno zajedno pruža empirijsku podršku i osigurava da se implementiraju učinkovite intervencije. 
Zaključno, pristup temeljen na dokazima učinkovitosti povećava učinkovitost i djelotvornost intervencija te osigurava stručnu (profesionalnu) odgovornost pri implementaciji (npr. poštivanje etičkih principa u radu s ljudima, ne stvarati štetu) usmjeravanjem resursa prema „onome što stvarno djeluje" na temelju dokaza istraživanja, a istovremeno ostavlja prostor za inovativni razvoj i procjenu novih strategija, na temelju iskustva članova zajednice i praktičara (HPIO, 2013).

\section{IZAZOVI KORIŠTENJA PRISTUPA TEMELJENOG NA DOKAZIMA UČINKOVITOSTI}

Dok sve veći broj praktičara vidi vrijednost pristupa temeljenog na dokazima učinkovitosti, istovremeno su svjesni i izazova uvođenja te održavanja takvog pristupa. Prilikom implementacije programa temeljenih na dokazima učinkovitosti praktičari moraju uravnotežiti dva prioriteta: vjernost provedbe i prikladnost zajednici (HHS, 2016). Kada je program temeljen na dokazima učinkovitosti vjerno implementiran, veće su šanse da će proizvesti slične rezultate kada se transportira na druga okruženja. S druge strane, dopuštanje određenih prilagodbi može povećati osjećaj lokalnog vlasništva nad programom. Pojedini praktičari ne preferiraju kada im je program temeljen na dokazima učinkovitosti nametnut jer imaju osjećaj da se tako zanemaruje njihovo profesionalno iskustvo. Dopuštajući lokalnu prilagodbu, praktičari mogu osjećati veću stopu vlasništva nad programom, što dovodi do veće kvalitete provedbe. Osim toga, određene modifikacije, kao što je kulturna prilagodba programa, mogu program učiniti atraktivnijim za sudionike, što će dovesti do boljih rezultata (Barrera, Berkel i Castro, 2017; Small i Huser, 2016). Dodavanje novih elemenata u program može se smatrati dodatnom vrijednošću, no praktičari moraju biti sigurni da dodatni materijali, aktivnosti i slično, ne narušavaju ili proturječe teorijskom utemeljenju programa ili načelima učinkovitih programa (Small i Huser, 2016). Naime, cilj adaptacija programa temeljenih na dokazima učinkovitosti je poboljšati doseg, angažman, djelotvornost i održivost programa, izmjenama koje odgovaraju jeziku, kulturnim vrijednostima i jedinstvenim rizičnim i zaštitnim čimbenicima sudionika programa (Cabassa i Baumann 2013). Generalno, nisu dozvoljene neopravdane izmjene originalnih programa temeljenih na dokazima učinkovitosti. Umjesto navedenog, važno je da se izmjenama u programu ne ugroze ključne komponente programa temeljenog na dokazima učinkovitosti (Barrera, Berkel i Castro, 2017; Castro i Baumann, 2013) te da su sve izmjene opravdane, obrazložene i dokumentirane te provjerene s autorima programa (Bernal i sur., 2009; Cardemil, 2010; Castro i sur., 2004; Lau, 2006, sve prema Barrera i sur., 2017).

Pristup temeljen na dokazima učinkovitosti temelji se na uvjerenju da intervencije trebaju biti temeljene na najboljim dostupnim dokazima. Općenito, najbolji dokazi dolaze iz dobro osmišljenih i provedenih RCT istraživanja ili meta-analiza brojnih RCT-ova (Egger, Smith, i O'Rourke, 2001, prema Mullen i Streiner, 2004). Upravo ovaj argument spominjao se kao značajna prednost korištenja pristupa temeljenog na dokazima učinkovitosti. Za razliku od medicine temeljene na dokazima učinkovitosti, koja se temelji na istraživanjima u visoko kontroliranim kliničkim uvjetima, prevencijska praksa temeljena na dokazima učinkovitosti temelji se na istraživanjima provedenim u složenim, stvarnim uvjetima koji često ne dopuštaju kontrolne skupine ili druge aspekte eksperimentalnih nacrta koji pomažu u utvrđivanju učinka određene intervencije (Cowen, Virk, Mascarenhas-Keyes i Cartwright, 2017; HPIO, 2013; Stewart-Brown i sur., 2011). Navedeno se često ne provodi upravo 
zbog praktičnih i etičkih razloga. Osim toga, postoje još brojni etički izazovi u provedbi pristupa temeljenog na dokazima učinkovitosti. Postavlja se pitanje postoji li uopće dovoljno kvalitetnih istraživanja kako bi se donosile odluke temeljene na dokazima učinkovitosti. Iznenađujuće za područje koje stavlja visoku vrijednost na istraživanje, a zapravo je relativno malo istraživanja izvrsne kvalitete kada se radi o učinkovitosti intervencija. Svakako, praktičari bi trebali imati na umu da kada donose odluke za koje postoji malo dokaza, trebaju biti dodatno oprezni u praćenju ishoda (Mullen i Streiner, 2004). Ujedno, odluke praktičara podložne su pristranosti, utjecaju javnog mnijenja i mnogim drugim pitanjima. Donošenje konačnih odluka zahtijeva otvorenost, napor i spremnost na promjene (Rith-Najarian, Daleiden i Chorpita, 2016). lako postoje dostupna istraživanja i podaci o tome što je učinkovito, činjenica je da za praktičare može biti izazovno procijeniti jesu li ograničenja istraživanja dovoljno ozbiljna da utječu na rezultate ili ih jednostavno treba tumačiti uz oprez (Mullen i Streiner, 2004). Uz navedeno, česti argument protiv korištenja pristupa temeljenog na dokazima učinkovitosti je da se radi o praksi „kuharice”, koja zamjenjuje profesionalnu prosudbu s receptima (HPIO, 2013). lako se temelji na dokazima učinkovitosti te su mišljenja praktičara, samo mišljenja, a ne dokazane istine, praktičar je osoba koja mora utvrditi je li dokaz primjenjiv na određeno pitanje pojedinca ili politike, imajući u vidu jedinstvene okolnosti. Baš kao što stručnost ne može biti izostavljena iz šire slike, isto tako ne mogu se izostaviti niti preferencije klijenta (Mullen i Streiner, 2004). Mnoge postojeće usluge ili programi tek trebaju biti uključeni u istraživanje, a to ograničava znanje o tome koji programi zapravo postižu najbolje rezultate (McKay, 2007). Uz navedeno, još je uvijek nedovoljno dokaza ili je malo onih koji istražuju dugoročne učinke pristupa temeljenog na dokazima učinkovitosti. Usluga koja je dokazana učinkovitom u jednom trenutku ne znači automatski da će imati dugoročne koristi (McKay, 2007; Small, Cooney, i O'Connor, 2009).

Osim toga, opći problem predstavlja zaostajanje dostupnosti programa temeljenih na dokazima učinkovitosti (istraživanja učinkovitosti) za nove probleme $s$ kojima se suočavaju pojedinci u suvremenom društvu. Budući da društveni problemi obično prethode istraživanjima, uvijek će postojati potreba za novim intervencijama. To znači da se resursi moraju posvetiti razvoju novih intervencija te testiranju i poboljšanju postojećih (Small i Huser, 2016). Kada je dostupan program temeljen na dokazima učinkovitosti koji je usklađen s potrebama ciljane publike tada je donošenje odluke o njegovoj implementaciji relativno jednostavna odluka (važno je još i postojanje političke/ profesionalne volje i dostupnost resursa).

lako postoji sve veći pritisak na donositelje odluka da koriste programe koji imaju dokaze o učinkovitosti, takvi programi obično zahtijevaju značajne financijske i ljudske resurse kako bi se pravilno proveli (McKay, 2007). Navedeno posebno predstavlja izazov za neprofitne organizacije (Bach-Mortensen, Lange i Montgomery, 2018; The Resource Center on Domestic Violence, 2016). Nažalost, mnoge lokalne organizacije obično nemaju pristup istoj razini financijskih sredstava i stručnosti osoblja kao institucije koje su izvorno osmislile i ocijenile intervencije (Small i Huser, 2016). Isto tako, prepreku predstavlja nedostatak podrške od strane donositelja odluka koji često kontroliraju financiranje takvih inicijativa (The Resource Center on Domestic Violence, 2016). Značajan dio problema leži u činjenici da donositelji odluka često ne prepoznaju vrijednosti takvih programa i samim time ne ulažu u njih. Jedan od najsnažnijih alata za iskazivanje vrijednosti takvih programa jest predstavljanje dokaza o budućim uštedama pomoću analize troškova i koristi (Small i Huser, 2016). 


\section{(PRED)UVJETI IMPLEMENTACIJA INTERVENCIJA TEMELJENIH NA DOKAZIMA UČINKOVITOSTI}

Usvajanje programa temeljenih na dokazima učinkovitosti zaostaje za rastom broja dostupnih programa. Vremenski razvoj između prakse temeljene na dokazima učinkovitosti i njezine integracije u rutinsku praksu procjenjuje se na 20 godina. lako je dostupan niz programa temeljenih na dokazima učinkovitosti te se znanost značajno bavila tim pitanjem i napredovala, praksa nažalost nije slijedila njezin tempo (Collins, 2011; Fishbein, Ridenour, Stahl i Sussman, 2016; Hoagwood, 2003-2004; Mihalic i Elliott, 2015). Unatoč tome što se pojedini program procjenjuje kao program temeljen na dokazima učinkovitosti, to ne znači automatski da je to pravi izbor za određenu zajednicu. Ključno je napraviti korak dalje od toga da se zajednicama pruži popis učinkovitih programa i sredstava za njihovu provedbu (Adams-Wolf i sur., 2016). Zajednice je potrebno potaknuti na uključivanje u izgradnju kapaciteta, procjenu potreba i trajnu evaluaciju (Adams-Wolf i sur., 2016). Programi temeljeni na dokazima učinkovitosti smatraju se „izdržljivim sjemenkama”, ali ne i „magičnim grahom". I najbolji program će biti neučinkovit u kaotičnoj i nestabilnoj zajednici u kojoj nedostaju osnovni resursi. Ujedno, valja imati na umu kako ne postoji samo jedan ispravni način organiziranja provedbe intervencija temeljenih na dokazima učinkovitosti. Na primjer, ne mora se isključivo provoditi u obliku programa, već se može integrirati u svakodnevni rad institucija ili službi, kao što su škole te zdravstvene i socijalne institucije (United Nations Office on Drugs and Crime, 2018). Hrvatski obrazovni sustav trenutno prolazi izazovnu tranziciju cjelokupnog kurikuluma. U tom pogledu, trenutna struja zagovaranja međupredmetnih tema vezanih uz primjerice Zdravlje (Odluka o donošenju kurikuluma za međupredmetnu temu Zdravlje za osnovne škole i srednje škole u Republici Hrvatskoj, NN 10/2019) i Osobni i socijalni razvoj (Odluka o donošenju kurikuluma za međupredmetnu temu Osobni i socijalni razvoj za osnovne i srednje škole u Republici Hrvatskoj, NN 7/2019) te uvođenje modernih metoda rada u škole i usmjerenost na razvoj socijalno-emocionalnih kompetencija učenika predstavlja značajan potencijal za kvalitetnu implementaciju pristupa temeljenih na dokazima učinkovitosti u školsko okruženje kroz cjeloživotno obrazovanje. Navedeno nije novina, s obzirom na to da se na globalnoj razini u školskim kurikulumima stavlja naglasak na razvoj socijalno emocionalnih vještina te dobrobiti učenika u školskom okruženju. Primjerice, u Norveškoj i Finskoj je razvoj socijalnih i emocionalnih vještina postavljen kao integrirani dio školskog kurikuluma (Restad, 2020). Samim time, postoji ogroman resurs koji je moguće iskoristiti kako bi se svim učenicima kroz cjeloživotno obrazovanje omogućilo jednak pristup usmjeren na pozitivan rast i razvoj, temeljen na dokazima učinkovitosti.

Bez obzira o kojem je pristupu riječ, potrebno je razriješiti brojna pitanja i uspostaviti sustav podrške kako bi se u konačnici primjenom intervencija temeljenih na dokazima učinkovitosti ostvarili ishodi - poboljšanje rezultata na razini zajednice i države (Brown i sur., 2015; Bumbarger i Owen, 2009; Hawkins i sur., 2010; O'Connell, Boat i Warner, 2009).

Jedno od važnih pitanja prilikom implementacije programa temeljenih na dokazima učinkovitosti u zajednice je pitanje spremnosti zajednice za provedbu programa. Program temeljen na dokazima učinkovitosti koji nije usklađen s potrebama zajednice vjerojatno će biti pogrešno usmjeren i predstavljati izgubljen napor. Ostvarivanje financiranja u današnje doba predstavlja značajan izazov te su samim time prihodi ograničeni, a donositelji odluka ne mogu si priuštiti da propadnu ulaganja u zajednicu zbog nerazriješenih pitanja spremnosti zajednice (Adams-Wolf i 
sur., 2016). Višestruki čimbenici mogu doprinijeti spremnosti zajednice za provedbu programa temeljenih na dokazima učinkovitosti, a ključni čimbenik je kontekst. U svakom kontekstu planiranja provedbe programa, kreatori politika i provoditelji postići će veći uspjeh ako postavljaju određena pitanja na vrijeme kako bi utvrdili spremnost zajednice. Samo neka od potencijalnih pitanja mogu biti (Bumbarger i Owen, 2009): „Koliko su jaki dokazi o učinkovitosti programa?”; „Koje su druge opcije?"; „Mogu li se primijeniti dokazi na ciljanu populaciju u zajednici?"; , Postoji li podrška kreatora programa?"; „'Što je potrebno za održavanje programa?"; , Vrijedi li ulagati i postoje li resursi?”; , Jesi li svi dionici potrebni za vjernu implementaciju programa dostupni?"; „Hoće li zajednica to smatrati prihvatljivim?"; „Koliko bi širok učinak mogao biti?” i slično. Učinkovita implementacija pristupa temeljenog na dokazima učinkovitosti zahtjeva vrijeme i uključenost svih dionika posebice onih na razini zajednice. Koraci koje je potrebno je napraviti su: napraviti organizacijsku analizu; pridobiti ključne dionike; analizirati ključne kontekstualne čimbenike; procijeniti trenutnu praksu u zajednici; osmisliti detaljan plan implementacije; identificirani specifičnu intervenciju temeljenu na dokazima; uvidjeti je li potrebno identificiranu intervenciju prilagoditi lokalnom kontekstu i ako je na koji način to napraviti; i kritički procijeniti cjelokupni proces uzimajući u obzir znanstvene dokaze i iskustvo te ekspertizu praktičara (Shapiro, Hawkins i Oestrele, 2015). Važno je da ključni ljudi i praktičari poduzmu sve korake koji su u njihovoj moći kako bi osigurali što veću spremnost zajednice za provedbu prije negoli se upuste u samu realizaciju pristupa temeljenog na dokazima učinkovitosti.

Drugo važno pitanje prilikom implementacije intervencije temeljenih na dokazima učinkovitosti u zajednici je pitanje osiguravanja kvalitete implementacije programa. Ključno za kreatore politika je osvještavanje da, iako donošenje propisa o implementaciji programa temeljenih na dokazima učinkovitosti predstavlja ključan korak prema pozitivnim ishodima, sam proces implementacije čini razliku između uspjeha i neuspjeha programa (Adams-Wolf i sur., 2016). Kao što je u prethodnom poglavlju spomenuto, izazov predstavlja kako uravnotežiti vjernost provedbe i prikladnost zajednici. Zagovornici vjernosti provedbe tvrde da prilagodba programa može ugroziti učinkovitost programa temeljenih na dokazima učinkovitosti (Aarons, 2017; Bass i Judge, 2010; Calsyn, Tornatzky i Dittmar, 1977; Chen, Reid, Parker i Pillemer, 2012; Durlak i DuPre, 2008). Nasuprot tome, drugi tvrde da je svaka provedba programa jedinstvena i da je potrebno postaviti pitanje "Kako i što će se promijeniti?", a ne "Treba li dopustiti prilagodbu?" (Chen i sur., 2012). lako su pojedini programi temeljeni na dokazima učinkovitosti opsežno prilagođeni za različite populacije, većina lokalnih prilagodbi nije dobro dokumentirana niti evaluirana (Escoffery i sur., 2018). Kao rezultat toga, empirijski dokazi često nedostaju u pogledu potencijalne učinkovitosti specifičnih prilagodbi koje praktičari razmatraju. Samim time, usporedbe prilagođenih i izvornih programa $\mathrm{u}$ istom istraživanju su rijetke, a nalazi među istraživanjima koje pružaju izravne usporedbe su neuvjerljivi (Alvidrez i sur., 2019). Podaci o vrstama prilagodbi koje se provode u praksi i njihovom utjecaju na djelotvornost i održivost programa bili bi od neprocjenjive važnosti za praktičare koji se suočavaju s donošenjem odluka o prilagodbi te bi posljedično značajno doprinijeli kvaliteti provedbe programa temeljenih na dokazima učinkovitosti.

I zadnje važno pitanje prilikom implementacije programa temeljenih na dokazima učinkovitosti u zajednice je pitanje održivosti programa temeljenih na dokazima učinkovitosti. Financijski izazovi predstavljaju značajnu prepreku primjeni programa temeljenih na dokazima učinkovitosti, kao što je opisano u prethodnom poglavlju. Najveći izazov predstavlja osiguravanje financiranja 
za dugoročnu provedbu programa, odnosno njegovu održivost. Naime, nerijetko se dogodi da se osiguraju sredstva za prvu provedbu programa (npr. projektno financiranje, najčešće iz Europskih fondova) i on postigne odlične rezultate, ali nakon toga ne nastavlja se njegova provedba, odnosno izostane nacionalna financijska podrška provedbi programa. Samim time, važno je razviti i slijediti konkretan plan održivosti na samom početku koji nadilazi traženje sljedećeg privremenog izvora financiranja (Bumbarger i Perkins, 2008; Scheirer i Dearing, 2011; Shelton, Cooper i Stirman, 2018).

Tijekom 19. i ranog 20. stoljeća, brojni preventivni programi smatrali su se učinkovitima, isključivo zbog njihovih dobrih namjera da se djeluje na određena ponašanja. Međutim, kako u svijetu financiranje programa preuzimaju savezne i državne vlasti, tako odgovornost o postizanju učinka programa raste, s početnim fokusom na dokumentiranje dosega programa pa sve do dokaza o učinkovitosti programa, dobivenih putem RCT istraživanja (Crowley i sur., 2018). U posljednjih nekoliko godina, fokus odgovornosti na postizanje učinka programa, proširio se i na ocjene o ekonomskim uštedama putem ulaganja u programe temeljene na dokazima učinkovitosti (Haskins and Margolis, 2015; National Academy of Medicine i sur., 2016, sve prema Crowley i sur., 2018). U interesu donositelja odluka, ali i javnosti jest da se javni resursi troše upravo na programe u kojima koristi od provedbe, nadmašuju troškove ulaganja. Washington State Institute for Public Policy ${ }^{7}$ (u daljnjem tekstu: WSIPP) jedan je od primjera koji koristi analize troškova i koristi, kako bi se sustavno i rutinski savjetovalo donositelje odluka. Cilj WSIPP-a je osigurati donositeljima odluka popis programa temeljenih na dokazima učinkovitosti, za koje postoje čvrsti dokazi da postižu željene učinke te da predstavljaju dobro i učinkovito ulaganje javnih resursa. lako je riječ o institutu u Washingtonu, na njihovim službenim stranicama moguće je pronaći informacije o brojnim programima koji se provode globalno. Primjerice, dostupne su informacije o znanstveno utemeljenom preventivnom programu PATHS, koji se između ostalog provodio i u Hrvatskoj. WSIPP (2019) navodi kako postoji $62 \%$ vjerojatnosti da će učinci PATHS programa nadmašiti njegove troškove. S obzirom da u hrvatskom kontekstu nije uobičajena provedba analiza troškova i koristi, podaci poput ovih koje osigurava WSIPP mogu biti od velike važnosti za zagovaranje ulaganja upravo u programe temeljene na dokazima učinkovitosti te poslužiti kao okvir za donošenje odluka.

\section{ZAKLJUČAK}

U ovom radu predstavljen je pristup temeljen na dokazima učinkovitosti, s posebnim naglaskom na analizu njegovih prednosti, prepreka i izazova u implementaciji. Kroz rad, moguće je uočiti da se pojedine činjenice navode kao prednosti, ali ujedno i kao prepreke, odnosno izazovi pristupa. Navedeno nije iznenađujuće, pogotovo ako se uzme u obzir da je riječ o kompleksnom pristupu koji zahtijeva da mu se pristupi s više različitih strana i razina te da se uzmu brojni čimbenici u obzir kako bi ostvario predviđene rezultate. Bez obzira na potencijalne prepreke i izazove, pristup temeljen na dokazima učinkovitosti je svakako vrijedan razmatranja za znanost, ali i za prevencijsku praksu.

lako se u protekla četiri desetljeća mnogo naučilo putem istraživanja na području prevencijske znanosti, još mnogo toga treba istražiti. Veliki prostor za buduća istraživanja predstavlja razvoj alata za prilagodbu programa, s obzirom na to da za sada ne postoji strategija "zlatnog standarda"

7 http://www.wsipp.wa.gov/ 
prilagodbe. Postoji mnogo načina na koje se prilagođeni program može smatrati poboljšanjem u odnosu na izvorni program. Činjenica je da pojedini pristupi mogu dobro funkcionirati u nekim okruženjima, ali ne i u svim okruženjima. Istraživanja bi se trebala usmjeriti na uspoređivanje različitih metoda prilagodbe, gdje rezultati uključuju troškove, ali i druge relevantne krajnje točke, kao što je doseg programa. Područje bi također trebalo razmotriti kako kvantificirati prednosti prilagodbe postojećeg programa u odnosu na izvorni program (Chen, Reid, Parker i Pillemer, 2012). Nadalje, buduća istraživanja trebala bi razviti i vrednovati nove preventivne prakse, programe i politike te nastaviti ocjenjivati učinkovitost postojećih o kojima je malo poznato, kako bi se zadovoljile novonastale potrebe ciljanih populacija.

Istraživanja su pokazala da se neprovjerene ili neučinkovite preventivne intervencije koriste češće od intervencija temeljenih na dokazima učinkovitosti (HHS, 2016; Brownson, Fielding i Green, 2019), a kada se koriste, intervencije nisu vjerno implementirane te često nisu održive (Bergmark, Bejerholm i Markström, 2019; Glasgow i sur., 2003; HHS, 2016). Ulaganja u neučinkovite i ponekad štetne intervencije predstavlja rasipanje prihoda koji su namijenjeni za područje prevencije, ali i posljedično potkopavaju povjerenje javnosti u prevencijsku znanost ako se ne postižu obećani i željeni rezultati. Bez ulaganja u kvalitetnu edukaciju svih dionika, teško je očekivati djelotvornu i učinkovitu primjenu pristupa temeljenog na dokazima učinkovitosti u praksu. Snažne argumente za implementaciju preventivnih intervencija temeljenih na dokazima učinkovitosti iznose i Spoth, Schainker, Redmond, Ralston, Yeh i Perkins (2015), poput: (1) poticanja veće usklađenosti između znanosti (dokaza učinkovitosti) i prakse, (2) usmjeravanja pažnje stručnjaka (praktičara) na učinkovite prakse/programe i (3) poboljšanja suradnje znanstvenika i praktičara.

Postoji jasna potreba za prevencijom problema u ponašanju mladih i za pozitivnim razvojem mladih te za širom i sustavnom primjenom preventivnih intervencija temeljenih na dokazima učinkovitosti. Kontinuirana ulaganja i javna zagovaranja vrijednosti pristupa temeljenog na dokazima učinkovitosti (u stručnoj javnosti te prema donositeljima odluka i kreatora politika) predstavljaju dobre temelje za postizanje učinkovite i djelotvorne prevencijske prakse. Implementacija preventivnih intervencija temeljenih na dokazima učinkovitosti, uz ulaganje napora da se odgovori na što je više moguće izazova pri njihovoj implementaciji, trebala bi postati standard jer je jedino tako moguće osigurati učinkovit i odgovoran odgovor na potrebe društva te ulagati u pozitivne ishode na svim razinama - pojedinac, okruženja u kojima pojedinac živi i društvo u cjelini.

\section{LITERATURA}

Aarons, G. A., Sklar, M., Mustanski, B., Benbow, N. i Brown, C. H. (2017). "Scaling-out" evidence-based interventions to new populations or new health care delivery systems. Implementation science, 12(1), 111. https://doi.org/10.1186/s13012-017-0640-6.

Adams-Wolf, M., Alter, J., Beals, N., Bozzel, D., Carrico, S., Gaillard, A., Gries, J., Lerch, J., Ross, S. i Sadler, K. (2016). Indiana's evidence based practice guide. Preuzeto s: https://secure.in.gov/fssa/ dmha/files/Indianas_Evidence_Based_Practice_Guide_Feb_16.pdf (10.02.2020.).

Alvidrez, J., Nápoles, A. M., Bernal, G., Lloyd, J., Cargill, V., Godette, D. i Farhat, T. (2019). Building the evidence base to inform planned intervention adaptations by practitioners serving heal- 
th disparity populations. American Journal of Public Health, 109(S1). https://doi.org/10.2105/ ajph.2018.304915.

Anderson, C. A. (2019). Assistive technology service delivery, a practical guide for disability and employment professionals. U A. F. Shay (ur.), Evidence-based practice (189-201). Menomonie, WI, United States: Elsevier.

Andrews, D. A. i Bonta, J. (2012). The psychology of criminal conduct (5th ed.). Newark, NJ.

Bach-Mortensen, A. M., Lange, B. i Montgomery, P. (2018). Barriers and facilitators to implementing evidence-based interventions among third sector organisations: a systematic review. Implementation science, 13(1), 103. https://doi.org/10.1186/s13012-018-0789-7.

Barrera, M., Berkel, C. i Castro, F. G. (2017). Directions for the advancement of culturally adapted preventive interventions: local adaptations, engagement, and sustainability. Prevention Science, 18(6), 640-648. https://doi.org/10.1007/s11121-016-0705-9.

Bass, D. i Judge, K. (2010). Challenges Implementing Evidence-Based Programs. Generations, 1, 51-58.

Bašić, J. (2009). Teorije prevencije: Prevencija poremećaja u ponašanju i rizičnih ponašanja djece $i$ mladih. Zagreb: Školska knjiga.

Ured za droge (n.d.). Baza projekata i programa. Preuzeto s: http://www.programi.uredzadroge.hr/ (15.04.2020.).

Bergmark, M., Bejerholm, U. i Markström, U. (2019). Implementation of evidence-based interventions: analyzing critical components for sustainability in community mental health services. Social Work in Mental Health, 17(2), 129-148. https://doi.org/10.1080/15332985.2018.1511500.

Blueprints (n.d.). Preuzeto s: https://www.blueprintsprograms.org/blueprints-certification/(15.04.2020.).

Brown, L. D., Feinberg, M. E., Shapiro, V. B. i Greenberg, M. T. (2015). Reciprocal relations between coalition functioning and the provision of implementation support. Prevention Science, 16(1), 101-109.

Brownson, R. C., Fielding J. E. i Maylahn, C. M. (2009). Evidence-based public health: A fundamental concept for public health practice. Annual Review of Public Health. Preuzeto s: https://www. annualreviews.org/doi/full/10.1146/annurev.publhealth.031308.100134 (11.5.2020.).

Brownson, R. C., Fielding, J. E. i Green, L. W. (2018). Building Capacity for Evidence-Based Public Health: Reconciling the Pulls of Practice and the Push of Research. Annual Review of Public Health, 39, 27-53. https://doi.org/10.1146/annurev-publhealth-040617-014746.

Bumbarger, B. K. i Perkins, D. F. (2008). After randomized trials: Issues related to dissemination of evidence-based interventions. Journal of Children's Services, 3(2), 53-61. https://doi. org/10.1108/17466660200800012.

Bumbarger, B. K. i Owen, J. (2009). The impact and cost-effectiveness of taking evidence-based prevention to scale: lessons learned from One State's experience. Preuzeto s: https://www.purdue. edu/hhs/hdfs/fii/wp-content/uploads/2015/07/s_ncfis05c05.pdf (11.05.2020.).

Burkhardt, J. T., Schröter, D. C., Magura, S., Means, S. N. i Coryn, C. L. (2015). An overview of evidence-based program registers (EBPRs) for behavioral health. Evaluation and program planning, 48, 92-99. https://doi.org/10.1016/j.evalprogplan.2014.09.006.

Buysse, V., Wesley, P. W., Snyder, P. i Winton, P. (2006). Evidence-based practice. Young Exceptional Children, 9(4), 2-11. https://doi.org/10.1177/109625060600900401. 
Cabassa, L. J. i Baumann, A. A. (2013). A two-way street: Bridging implementation science and cultural adaptations of mental health treatments. Implementation Science, 8, 1-14. https://doi. org/10.1186/1748-5908-8-90.

Calsyn, R., Tornatzky, L. G. i Dittmar, S. (1977). Incomplete adoption of innovation: The case of goal attainment scaling. Evaluation, 4, 128-130.

Castro, F. G., Barrera,M., Jr. i Holleran Steiker, L. K. (2010). Issues and challenges in the design of culturally adapted evidence-based interventions. Annual Review of Clinical Psychology, 6, 213-239. https://doi.org/10.1146/annurev-clinpsy-033109-132032

Chen, E. K., Reid, M. C., Parker, S. J. i Pillemer, K. (2012). Tailoring evidence-based interventions for new populations. Evaluation \& the Health Professions, 36(1), 73-92. https://doi. org/10.1177/0163278712442536.

Collins, F. S. (2011). Reengineering Translational Science: The time is right. Science Translational Medicine, 3(90). https://doi.org/10.1126/scitranslmed.3002747.

Cowen, N., Virk, B., Mascarenhas-Keyes, S. i Cartwright, N. (2017). Randomized controlled trials: How can we know "what works"? Critical Review, 29(3), 265-292. https://doi.org/10.1080/0891 3811.2017.1395223.

Crime and Justice Institute at Community Resources for Justice (2009). Implementing Evidence-Based Policy and Practice in Community Corrections, 2nd ed. Washington, DC: National Institute of Corrections. Preuzeto s: https://s3.amazonaws.com/static.nicic.gov/Library/024107.pdf (8.5.2020.).

Crowley, D. M., Dodge, K. A., Barnett, W. S., Corso, P., Duffy, S., Graham, P., Greenberg, M., Haskins, R., Hill, L., Jones, D. E., Karoly, L. A., Kuklinski, M. R. i Plotnick, R. (2018). Standards of Evidence for Conducting and Reporting Economic Evaluations in Prevention Science. Prevention Science, 19(3), 366-390. https://doi.org/10.1007/s11121-017-0858-1

Durlak, J. i DuPre, E. (2008). Implementation matters: A review of research on the influence of implementation on program outcomes and factors affecting implementation. American Journal of Community Psychology, 41, 327-350. https://doi.org/10.1007/s10464-008-9165-0

European Monitoring Centre for Drugs and Drug Addiction (2019). European Prevention Curriculum: a handbook for decision-makers, opinion-makers and policy-makers in science-based prevention of substance use. Luxembourg: Publications Office of the European Union.

European Monitoring Center for Drugs and Drug Adiction (EMCCDA) (n.d.). Preuzeto s: https:// www.emcdda.europa.eu/best-practice/xchange/about (14.04.2020).

Evidence-Based Medicine Working Group (1992). Evidence-Based Medicine: A New Approach to Teaching the Practice of Medicine. Journal of American Medical Association, 268(17), 2420-2425. https://doi.org/10.1001/jama.1992.03490170092032.

Escoffery, C., Lebow-Skelley, E., Haardoerfer, R., Boing, E., Udelson, H., Wood, R., Hartman, M, Fernandez, M. E. i Mullen, P.D. (2015). A systematic review of adaptations of evidence-based public health interventions globally. Implementation Science 13, 125. https://doi.org/10.1186/ s13012-018-0815-9.

Fishbein, D. H., Ridenour, T. A., Stahl, M. i Sussman, S. (2016). The full translational spectrum of prevention science: facilitating the transfer of knowledge to practices and policies that prevent behavioral health problems. Translational Behavioral Medicine, 6(1), 5-16. https://doi.org/10.1007/ s13142-015-0376-2. 
Glasgow R. E, Lichtenstein E. i Marcus A. C. (2003). Why don't we see more translation of health promotion research to practice? Rethinking the efficacy-to-effectiveness transition. Annual Review of Public Health, 93(8), 1261-7. https://doi.org/10.2105/ajph.93.8.1261

Gottfredson, D. C., Cook, T. D., Gardner, F. E. M., Gorma-Smith, D., Howe G. W., Sandler, I. N. i Zafft, K. (2015). Standards of evidence for efficacy, effectiveness, and scale-up research in prevention science: Next generation. Prevention Science, 16, 893-926. https://doi.org/10.1007/s 11121-0150555-x.

Hailemariam, M., Bustos, T., Montgomery, B., Barajas, R., Evans, L. B. i Drahita, A. (2019). Evidence-based intervention sustainability strategies: a systematic review. Implementation Science, 14, 57. https://doi.org/10.1186/s13012-019-0910-6.

Hariton, E. i Locascio, J. J. (2018). Randomised controlled trials - the gold standard for effectiveness research: Study design: randomised controlled trials. BJOG: an international journal of obstetrics and gynaecology, 125(13), 1716. https://doi.org/10.1111/1471-0528.15199.

Hawkins, J. D., Shapiro, V. B. i Fagan, A. A. (2010). Disseminating Effective Community Prevention Practices: Opportunities for Social Work Education. Research on Social Work Practice, 20(5), 518-527. https://doi.org/10.1177/1049731509359919.

Health policy institute of Ohio (HPIO). (2013). The online guide to evidence - based prevention. Preuzeto s: https://nnphi.org/wp-content/uploads/2015/08/GuideToEvidence-BasedPrevention. pdf (15.04.2020.).

Hoagwood, K. (2003-2004). Evidence-based practice in child and adolescent mental health: Its meaning, application and limitations. Emotional and Behavioral Disorders in Youth, 4, 7-8.

McKay, C. E. (2007). Evidence based practices in mental health: advantages, disadvantages, and research considerations. Preuzeto s: $h$ ttps://escholarship.umassmed.edu/pib/vol4/iss5/1/(28.04.2020.).

Mihalic, S. F. i Elliott, D. S. (2015). Evidence-based programs registry: Blueprints for healthy youth development. Evaluation and Program Planning, 48, 124-131.

Model Programs Guide: Office of Juvenile Justice and Delinquency Prevention, U.S. (n.d.). Preuzeto s: https://www.ojjdp.gov/MPG/Home/About (14.04.2020.).

Mullen, E. J. i Streiner, D. L. (2004). The evidence for and against evidence-based practice. Brief Treatment and Crisis Intervention, 4(2), 111-121. https://doi.org/10.1093/brief-treatment/mhh009.

O'Connell, M. E., Boat, T. i Warner, K. E. (2009). Preventing mental, emotional, and behavioral disorders among young people: Progress and possibilities. Washington, DC: National Academies Press.

Odluka o donošenju kurikuluma za međupredmetnu temu Osobni i socijalni razvoj za osnovne i srednje škole u Republici Hrvatskoj. Narodne novine, 87/08, 86/09, 92/10, 105/10, 90/11, 16/12, 86/12, 94/13, 152/14, 7/17, 68/18, 7/19.

Odluka o donošenju kurikuluma za međupredmetnu temu Zdravlje za osnovne škole i srednje škole u Republici Hrvatskoj. Narodne novine, 87/08, 86/09, 92/10, 105/10 - ispravak, 90/11, 16/12, $86 / 12,94 / 13,152 / 14,7 / 17,68 / 18,10 / 19$.

Pew Cheritable Trust (2016). Implementation Oversight for Evidence-Based Programs. Preuzeto s: https://www.pewtrusts.org/en/research-and-analysis/issue-briefs/2016/05/implementation-oversight-for-evidence-based-programs (04.05.2020.).

Portney, L.G. (2020). Foundations of Clinical Research: Applications to Evidence-Based Practice (4th edition). Philadelphia: FA Davis. 
Prendergast M. L. (2011). Issues in defining and applying evidence-based practices criteria for treatment of criminal-justice involved clients. Journal of psychoactive drugs, 7, 10-18. https:// doi.org/10.1080/02791072.2011.601984.

Przybylski, R. i Orchowsky, S. (2015). Implementing evidence-based practices. Washington, DC: Justice Research and Statistics Association. Preuzeto s: https://www.jrsa.org/projects/ebp_briefing_paper2.pdf (5.5.2020.).

Rith-Najarian, L. R., Daleiden, E. L. i Chorpita, B. F. (2016). Evidence-based decision making in youth mental health prevention. American Journal of Preventive Medicine, 51(4). https://doi. org/10.1016/j.amepre.2016.05.018.

Restad, F. (2020). Is There a Hole in the Whole-School Approach? A Critical Review of Curriculum Understanding in Bullying Research. Nordic Studies in Education, 40(4), 362-386. https://doi. org/10.23865/nse.v40.2610

Rousseau, D.M. i Gunia, B.C. (2016). Evidence-Based Practice: The Psychology of EBP Implementation. Annual Review of Psychology, 67, 667-692. https://doi.org/10.1146/annurev-psych-122414-033336.

Scheirer, M. A. i Dearing, J. W. (2011). An agenda for research on the sustainability of public health programs. American journal of public health, 101(11), 2059-67.

Shapiro, V. B., Hawkins, J. D. i Oesterle, S. (2015). Building local infrastructure for community adoption of science-based prevention: The role of coalition functioning. Prevention science, 16(8), 1136-1146. https://doi.org/10.1007/s11121-015-0562-y.

Shelton, R. C., Cooper, B. R. i Stirman, S. W. (2018). The Sustainability of Evidence-Based Interventions and Practices in Public Health and Health Care. Annual Review of Public Health, 39(1), 55-76. https://doi.org/10.1146/annurev-publhealth-040617-014731.

Small, S. A., Cooney, S. M. i O'Connor, C. (2009). Evidence-informed program improvement: Using principles of effectiveness to enhance the quality and impact of family-based prevention programs. Family Relations, 58(1), 1-13. https://doi.org/10.1111/j.1741-3729.2008.00530.x.

Small, A. i Huser, M. (2016). Encyclopedia of adolescence. U R. J. R. Levesque (ur.), Family-based prevention programs (1-11). Switzerland: Springer.

Spoth, R., Schainker, L. M., Redmond, C., Ralston, E., Yeh, H. C. i Perkins, D. F. (2015). Mixed picture of readiness for adoption of evidence-based prevention programs in communities: exploratory surveys of state program delivery systems. American Journal of Community Psychology, 55(3-4), 253-265. https://doi.org/10.1007/s 10464-015-9707-1.

Steglitz, J., Wright, J. D., Warnick, J. L., Hoffman, S. A., Johnston, W. i Spring, B. (2015). Evidence-based practice. U International Encyclopedia of Social and Behavioral Sciences, 2nd edition, Vol 8 (332-338). London: Oxford Elsevier.

Stewart-Brown, S. Anthony R., Wilson, L., Winstanley, S., Simkiss, D., Stallard, N. i Snooks, H. (2011). Should randomised controlled trials be the "gold standard" for research on preventive interventions for children? Journal of Children's Services, 6(4), 228-235. https://doi. org/10.1108/17466661111190929

Tomlinson, M., Ward, C. L. i Marlow, M. (2015). Improving the efficiency of evidence-based interventions: The strengths and limitations of randomised controlled trials. SA Crime Quarterly, 51, 43-52. https://doi.org/10.4314/sacq.v51i1.5.

The Resource Center on Domestic Violence: Child Protection and Custody (2016). Moving Toward Evidence-Based Practices: A Guide for Domestic Violence Organizations. Reno, NV: Author. 
The What Works Clearinghouse: Institute of Educational Sciences (IES), U.S. Department of Education (n.d.). Preuzeto s: http://ies.ed.gov/ncee/wwc/ (15.04.2020.).

Trinder, L. i Reynolds, S. (2006). Evidence-based practice: A critical appraisal. Oxford: Blackwell Science.

Tucker, J. A. i Reed, G. M. (2008). Evidentiary pluralism as a strategy for research and evidence-based practice in rehabilitation psychology. Rehabilitation Psychology, 53(3), 279-293.

United Nations Office on Drugs and Crime (UNDOC) (2018). International Standards on Drug Use Prevention, Second updated edition. Vienna: UNDOC/WHO.

Ured za suzbijanje zlouporabe droga Vlada Republike Hrvatske (n.d.). Preuzeto s: https://drogeiovisnosti.gov.hr/baza-projekata-i-programa-koji-se-provode-u-podrucju-suzbijanja-zlouporabe-droga/938 (15.04.2020.).

U.S. Department of Health and Human Services (HHS). (2016). Facing addiction in America: The Surgeon general's report on alcohol, drugs, and health. Preuzeto s: https://addiction.surgeongeneral.gov/sites/default/files/surgeon-generals-report.pdf (04.05.2020.).

Washington State Institute of Public Policy's (WSIPP) (2012). Evidence-based practice institute. Preuzeto s: http:// depts.washington.edu/ebpi/ (07.04.2020.).

Washington State Institute for Public Policy (WSIPP) (2018). Promoting Alternative Thinking Strategies (PATHS). Preuzeto s: http://www.wsipp.wa.gov/BenefitCost/Program/94 (02.02.2021.).

Williams-Taylor, L. (2007). Evidence-based programs and practices: What does it all mean? Boynton Beach, FL: Research Review, Children's Services Council of Palm Beach County. Preuzeto s: http:// citeseerx.ist.psu.edu/viewdoc/download?doi=10.1.1.177.90\&rep=rep 1\&type =pdf (5.5.2020.). 


\title{
IMPLEMENTATION OF AN EVIDENCE-BASED APPROACH IN PREVENTION SCIENCE
}

\section{Matea Belošević Martina Ferić}

Laboratory for prevention research (PrevLab), Department of Behavioural Disorders, Faculty of Education and Rehabilitation Sciences, University of Zagreb

\begin{abstract}
The purpose of this paper is to critically review the evidence-based approach, from defining key terms to analyzing the advantages and barriers to its implementation in practice. The paper discusses the evidence-based approach, i.e. it defines the terms "evidence-based practice" and "evidence-based programs/interventions". It critically examines the key criteria of evidence-based programs/interventions. The main online databases of evidence-based programs and categories used in determining the different levels of effectiveness of the program/intervention are described. In addition, the advantages, as well as the challenges, of evidence-based approach and its implementation are discussed and evaluated. The conclusion includes proposed guidelines for future research on effective and efficient selection and application of evidence-based approaches in prevention practice.
\end{abstract}

Keywords: prevention science, programs, evidence-based approach, advantages, barriers 